\section{Influence of curing conditions on recycled aggregate concrete}

C. Thomas $^{\mathrm{a}, *}$

carlos.thomas@unican.es

J. Setién

J.A. Polanco

C.

aLADICIM (Laboratory of Materials Science and Engineering), University of Cantabria. E.T.S. de Ingenieros de Caminos, Canales y Puertos, Av/Los Castros 44, 39005 Santander, Spain

'University of Extremadura, UEX-CSIC Partnering Unit, School of Civil Engineering, Avda. de la Universidad, s/n, Cáceres, Spain

*Corresponding author

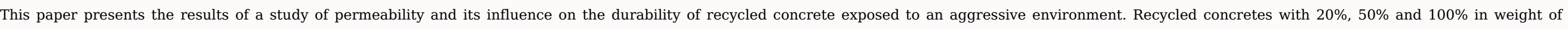

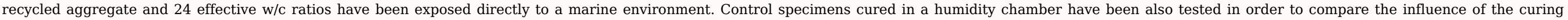

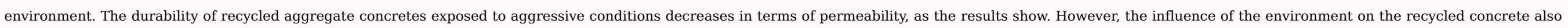

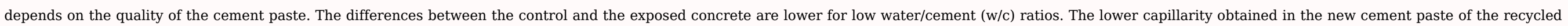
concretes with low w/c ratios isolates the porosity of the recycled aggregate, increasing the durability but with a rise in the cement content.

Keywords: Waste; Recycled aggregate concrete; Marine environment; Recycling; Mechanical testing; Durability

\section{Introduction}

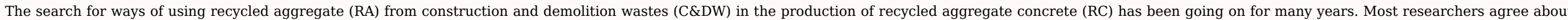

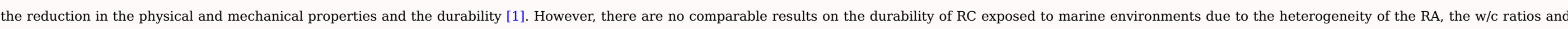

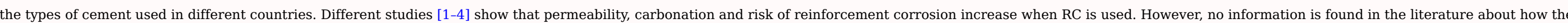

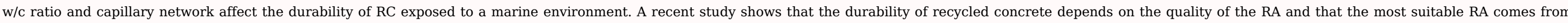

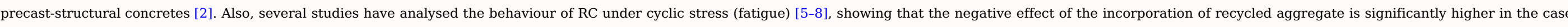

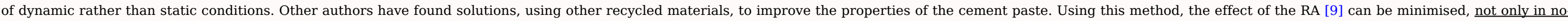

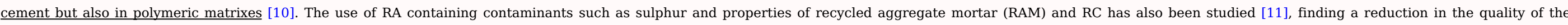
concrete proportional to the quality of the recycled aggregate.

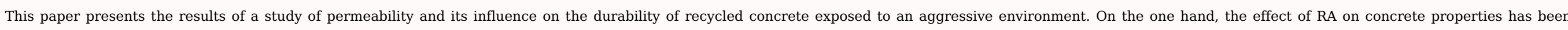

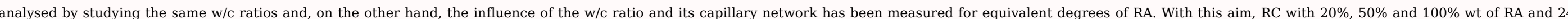
effective w/c ratios have been exposed directly to a marine environment.

\section{Experimental program}

(2018. This manuscript version is made available under the CC-BY-NC-ND 4.0

license http://creativecommons.org/licenses/by-nc-nd/4.0/ 


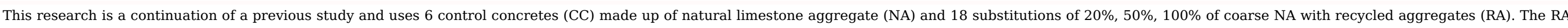

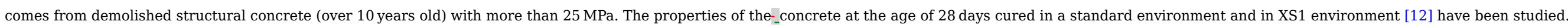

\subsection{Materials}

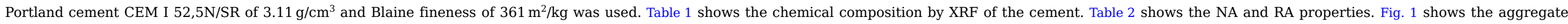
grading including the natural sand (NS).

Table 1 Chemical composition of the cement.

\begin{tabular}{|c|c|c|c|c|c|c|c|c|c|}
\hline Component: & $\mathrm{CaO}$ & $\mathrm{SiO}_{2}$ & $\mathrm{SO}_{3}$ & $\mathrm{Al}_{2} \mathrm{O}_{3}$ & $\mathrm{Fe}_{2} \mathrm{O}_{3}$ & $\mathrm{MgO}$ & $\mathrm{K}_{2} \mathrm{O}$ & $\mathrm{TiO}_{2}$ & C \\
\hline$\%$ in wt: & 69.60 & 18.60 & 3.22 & 3.10 & 2.66 & 1.17 & 0.54 & 0.17 & 0.47 \\
\hline
\end{tabular}

Table 2 Properties of the aggregate.

\begin{tabular}{|c|c|c|c|c|c|c|}
\hline Aggregate & $\operatorname{Dr}\left[\mathrm{g} / \mathrm{cm}^{3}\right]$ & Dssds $\left[\mathrm{g} / \mathrm{cm}^{3}\right]$ & $\mathrm{A}[\% \mathrm{wt}]$ & $\mathrm{P}[\% \mathrm{v}]$. & $\mathrm{Dc}\left[\mathrm{g} / \mathrm{cm}^{3}\right]$ & LA [\%] \\
\hline NA $(6 / 12)$ & 2.510 & 2.550 & 1.80 & 4.70 & 1.530 & 31.0 \\
\hline NA $(12 / 20)$ & 2.540 & 2.590 & 1.60 & 4.00 & 1.530 & - \\
\hline RA (6/20) & 2.320 & 2.310 & 5.30 & 12.30 & 1.420 & 42.0 \\
\hline
\end{tabular}

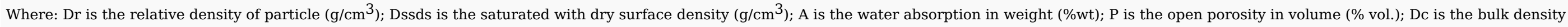
$\left(\mathrm{g} / \mathrm{cm}^{3}\right)$; LA is the Los Angeles index (\%).

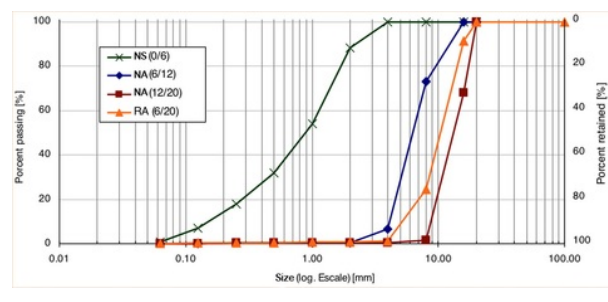

Fig. 1 Grading of the natural and recycled aggregates.

\subsection{Mix proportions}

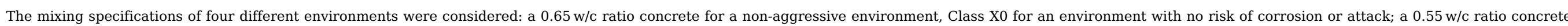

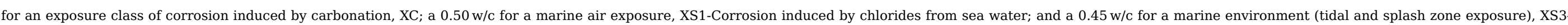

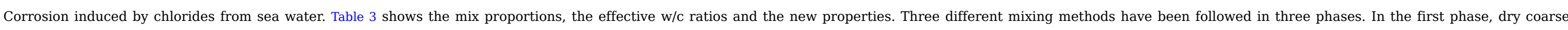

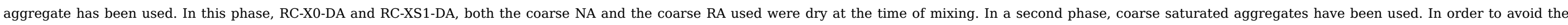

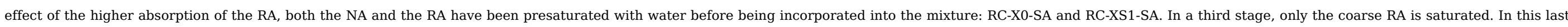

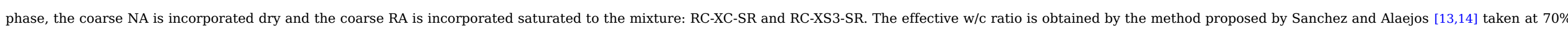
of the absorption capacity during mixing using dry aggregates.

Table 3 Concrete mix proportions and fresh properties. 


\begin{tabular}{|c|c|c|c|c|c|c|c|c|c|c|c|c|c|c|c|c|c|c|c|c|c|c|c|c|}
\hline \multirow{2}{*}{$\begin{array}{l}\text { Designation } \\
\text { RA content }\end{array}$} & \multicolumn{4}{|c|}{ RC-X0-DA } & \multicolumn{4}{|c|}{ RC-X0-SA } & \multicolumn{4}{|c|}{ RC-XC-SR } & \multicolumn{4}{|c|}{ RC-XS1-DA } & \multicolumn{4}{|c|}{ RC-XS1-SA } & \multicolumn{4}{|c|}{ RC-XS3-SR } \\
\hline & $0 \%$ & $20 \%$ & $50 \%$ & $100 \%$ & $0 \%$ & $20 \%$ & $50 \%$ & $100 \%$ & $0 \%$ & $20 \%$ & $50 \%$ & $100 \%$ & $0 \%$ & $20 \%$ & $50 \%$ & $100 \%$ & $0 \%$ & $20 \%$ & $50 \%$ & $100 \%$ & $0 \%$ & $20 \%$ & $50 \%$ & $100 \%$ \\
\hline NS (kg): & 840 & 880 & 850 & 870 & 950 & 960 & 980 & 1010 & 875 & 800 & 830 & 825 & 715 & 745 & 710 & 715 & 805 & 815 & 820 & 835 & 815 & 700 & 740 & 745 \\
\hline NA $(12 / 20)(\mathrm{kg}):$ & 750 & 565 & 350 & 0 & 515 & 380 & 210 & 0 & 755 & 630 & 370 & 0 & 880 & 665 & 415 & 0 & 700 & 520 & 290 & 0 & 870 & 750 & 430 & 0 \\
\hline NA $(6 / 12)(\mathrm{kg}):$ & 226 & 170 & 105 & 0 & 490 & 362 & 200 & 0 & 255 & 210 & 125 & 0 & 120 & 90 & 60 & 0 & 330 & 245 & 135 & 0 & 170 & 145 & 85 & 0 \\
\hline RA $(12 / 20)(\mathrm{kg}):$ & 0 & 185 & 455 & 830 & 0 & 185 & 410 & 640 & 0 & 210 & 490 & 925 & 0 & 190 & 470 & 875 & 0 & 190 & 430 & 685 & 0 & 225 & 515 & 965 \\
\hline Cement (kg): & 275 & 275 & 275 & 275 & 275 & 275 & 275 & 275 & 325 & 325 & 325 & 325 & 380 & 380 & 380 & 380 & 380 & 380 & 380 & 380 & 385 & 385 & 385 & 385 \\
\hline Water $(\mathrm{kg})$ : & 180 & 180 & 180 & 180 & 180 & 180 & 180 & 180 & 180 & 180 & 180 & 180 & 190 & 190 & 190 & 190 & 190 & 190 & 190 & 190 & 173 & 173 & 173 & 173 \\
\hline Effective w/c ratio: & 0.60 & 0.59 & 0.57 & 0.54 & 0.67 & 0.68 & 0.67 & 0.70 & 0.51 & 0.52 & 0.54 & 0.58 & 0.46 & 0.45 & 0.44 & 0.42 & 0.53 & 0.53 & 0.53 & 0.52 & 0.42 & 0.42 & 0.44 & 0.49 \\
\hline Slump (cm): & 17 & 21 & 16 & 15 & 15 & 18 & 17 & 17 & 16 & 15 & 17 & 18 & 16 & 18 & 15 & 14 & 20 & 19 & 18 & 21 & 18 & 17 & 17 & 19 \\
\hline
\end{tabular}

\subsection{Specimens and curing conditions}

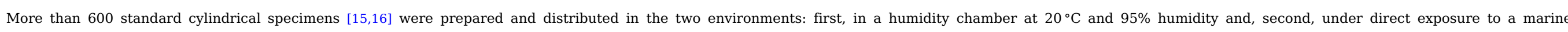
environment: Type IIIa with a one-year average temperature of $13.9 \pm 5^{\circ} \mathrm{C}$ temperature and $74.3 \pm 2 \%$ humidity.

\subsection{Mechanical properties}

A Compressive strength test $[17,18]$ and a Tensile splitting test [19] were performed on 3 specimens of each mix with 28 days curing. The modulus of elasticity was performed following the standard [20].

\subsection{Physical properties}

Standard [21] was followed in order to obtain the physical properties. Also, the water absorption coefficient and the open porosity of the concrete were determined.

\subsection{Permeability}

The maximum water penetration was determined following standard [22]. The oxygen permeability coefficient was determined according to [23].

\subsection{Accelerated chloride penetration}

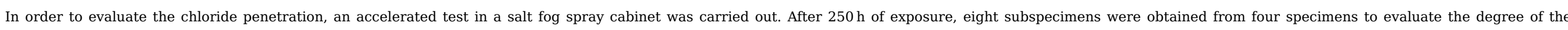

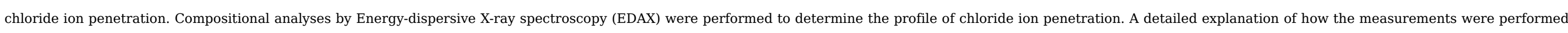
is provided in [11].

\section{Results and discussions}

The results and discussion are presented in this section. The results of the concretes cured in a marine environment are compared with the results of the concretes cured in a humidity chamber [1]

\subsection{Mechanical properties}

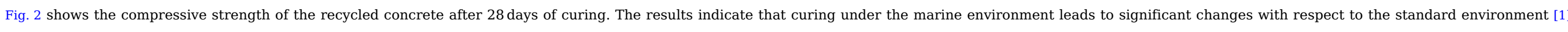

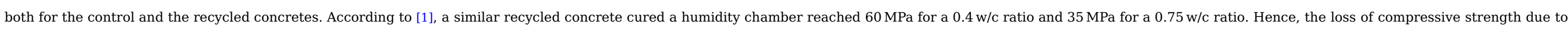

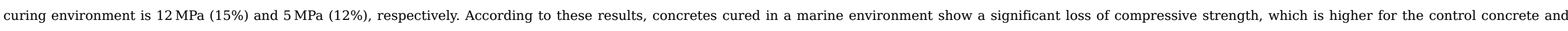

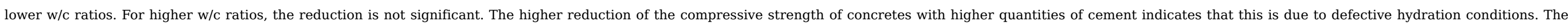




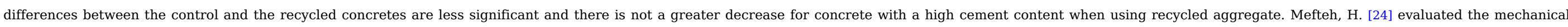

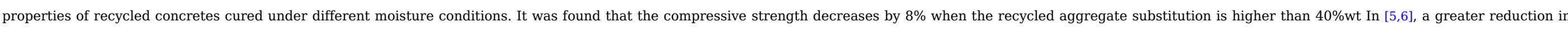

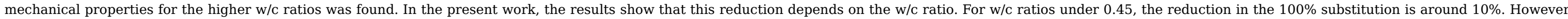
for $w / c$ ratios over 0.65 , the reduction due to the marine environment is situated around $6 \%$.

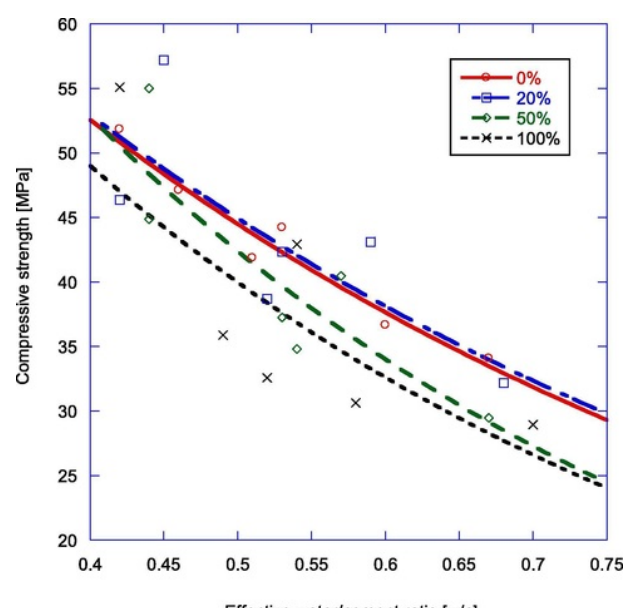

Fig. 2 Compressive strength of recycled concretes with 28 days cured into marine environment.

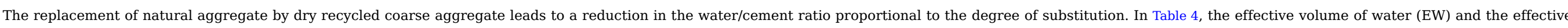

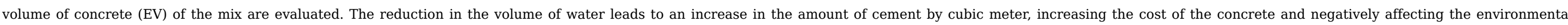

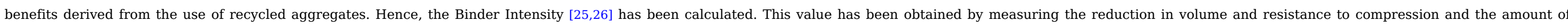

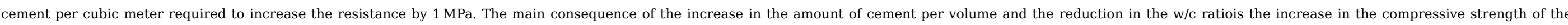

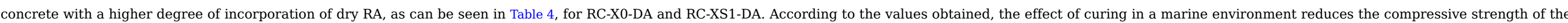
$100 \%$ recycled concrete to a value equivalent to a loss of $4.5 \% \mathrm{wt}$ of the content of cement, being more significant for low w/c concretes.

Table 4 Mechanical properties of concretes and binder index.

\begin{tabular}{|c|c|c|c|c|c|c|c|c|c|c|c|c|c|c|c|c|c|c|c|c|c|c|c|c|}
\hline \multirow{2}{*}{$\begin{array}{l}\text { Designation } \\
\text { RA content: }\end{array}$} & \multicolumn{4}{|c|}{ RC-X0-DA } & \multicolumn{4}{|c|}{ RC-X0-SA } & \multicolumn{4}{|c|}{ RC-XC-SR } & \multicolumn{4}{|c|}{ RC-XS1-DA } & \multicolumn{4}{|c|}{ RC-XS1-SA } & \multicolumn{4}{|c|}{ RC-XS3-SR } \\
\hline & $0 \%$ & $20 \%$ & $50 \%$ & $100 \%$ & $0 \%$ & $20 \%$ & $50 \%$ & $100 \%$ & $0 \%$ & $20 \%$ & $50 \%$ & $100 \%$ & $0 \%$ & $20 \%$ & $50 \%$ & $100 \%$ & $0 \%$ & $20 \%$ & $50 \%$ & $100 \%$ & $0 \%$ & $20 \%$ & $50 \%$ & $100 \%$ \\
\hline CS HC (MPa): & 37.64 & 41.22 & 42.53 & 44.87 & 36.13 & 32.39 & 30.7 & 29.71 & 51.3 & 50.3 & 54.25 & 55.57 & 45.01 & 43.25 & 40.63 & 40.92 & 47.19 & 43.44 & 40.54 & 32.9 & 57.98 & 52.9 & 44.92 & 40.12 \\
\hline CS ME (MPa): & 36.67 & 43.11 & 40.49 & 42.91 & 34.08 & 32.17 & 29.48 & 28.94 & 47.12 & 57.19 & 55.01 & 55.09 & 44.22 & 42.33 & 37.25 & 32.6 & 41.85 & 38.71 & 34.81 & 30.64 & 51.83 & 46.38 & 44.85 & 35.9 \\
\hline EW $\left(m^{3}\right):$ & 165.0 & 162.2 & 156.7 & 148.5 & 184.2 & 187 & 184.2 & 192.5 & 174.8 & 171.0 & 167.2 & 159.6 & 201.4 & 201.4 & 201.4 & 197.6 & 165.7 & 169.0 & 175.5 & 188.5 & 161.7 & 161.7 & 169.4 & 188.6 \\
\hline $\operatorname{EV}\left(m^{3}\right):$ & 0.986 & 0.983 & 0.978 & 0.970 & 1.005 & 1.008 & 1.005 & 1.014 & 0.985 & 0.981 & 0.977 & 0.970 & 1.011 & 1.011 & 1.011 & 1.008 & 0.987 & 0.990 & 0.997 & 1.010 & 0.989 & 0.989 & 0.996 & 1.016 \\
\hline $\mathrm{C} / \mathrm{EV}\left(\mathrm{kg} / \mathrm{m}^{3}\right):$ & 278.9 & 279.7 & 281.3 & 283.7 & 273.6 & 272.8 & 273.6 & 271.3 & 385.9 & 387.4 & 388.9 & 391.9 & 375.7 & 375.7 & 375.7 & 377.1 & 329.4 & 328.3 & 326.1 & 321.9 & 389.4 & 389.4 & 386.4 & 379.1 \\
\hline BI HC $\left(\mathrm{kg} / \mathrm{m}^{3} \cdot \mathrm{MPa}^{-1}\right)$ : & 7.4 & 6.8 & 6.6 & 6.3 & 7.6 & 8.4 & 8.9 & 9.1 & 7.5 & 7.7 & 7.2 & 7.1 & 8.3 & 8.7 & 9.2 & 9.2 & 7.0 & 7.6 & 8.0 & 9.8 & 6.7 & 7.4 & 8.6 & 9.4 \\
\hline $\mathrm{BI}-\mathrm{ME}\left(\mathrm{kg} / \mathrm{m}^{3} \cdot \mathrm{MPa}^{-1}\right)$ & 7.6 & 6.5 & 6.9 & 6.6 & 8.0 & 8.5 & 9.3 & 9.4 & 8.2 & 6.8 & 7.1 & 7.1 & 8.5 & 8.9 & 10.1 & 11.6 & 7.9 & 8.5 & 9.4 & 10.5 & 7.5 & 8.4 & 8.6 & 10.6 \\
\hline
\end{tabular}


CS HC is the compressive strength of the concrete cured into the humidity chamber;

CS ME: is the compressive strength of the concrete cured into the marine environment;

$\mathrm{EW}$ is the effective water volume;

$\mathrm{EV}$ is the effective volume of concrete;

$\mathrm{C} / \mathrm{EV}$ is the cement/concrete volume index;

$\mathrm{BI} \mathrm{HC}$ is the Binder Index of the concrete cured into the humidity chamber;

$\mathrm{BI} \mathrm{ME}$ is the Binder Index of the concrete cured into the marine environment.

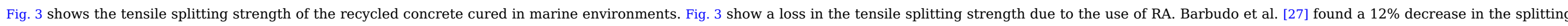

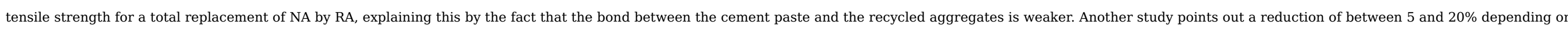

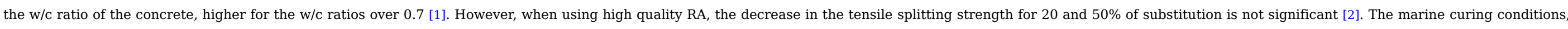
worse than the standard ones, attenuate the negative effect of the RA on the mechanical properties.

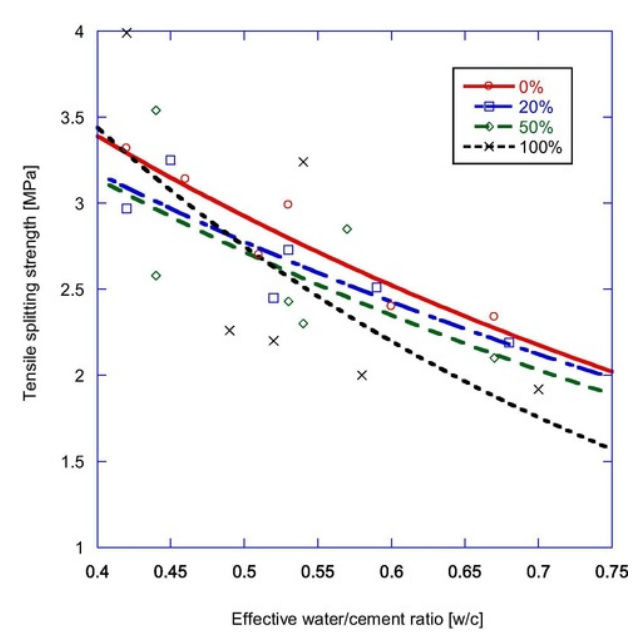

Fig. 3 Tensile splitting strength of recycled concretes with 28 days cured into marine environment.

\subsection{Relative density}

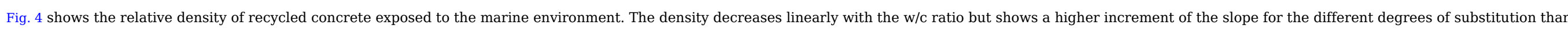

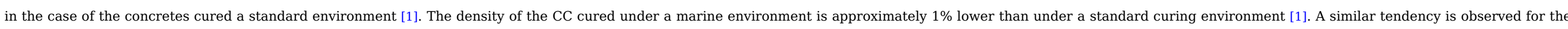

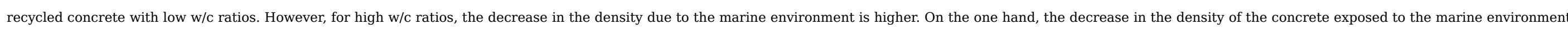

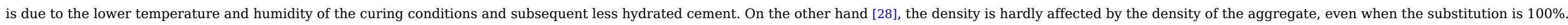




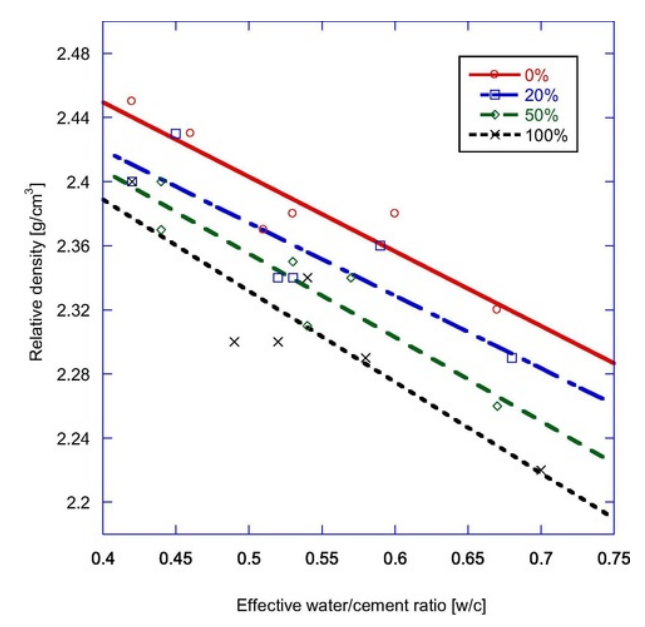

Fig. 4 Relative density of recycled concretes with 28 days cured into marine environment.

\subsection{Absorption coefficient}

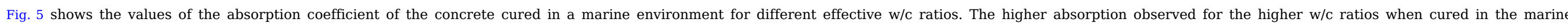

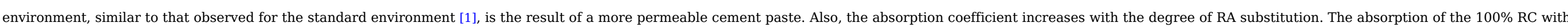

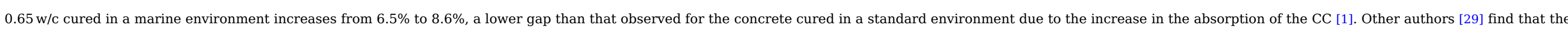

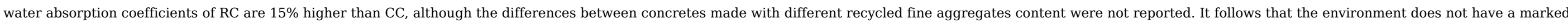

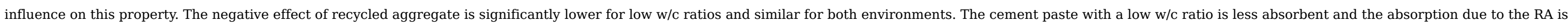
in part isolated.

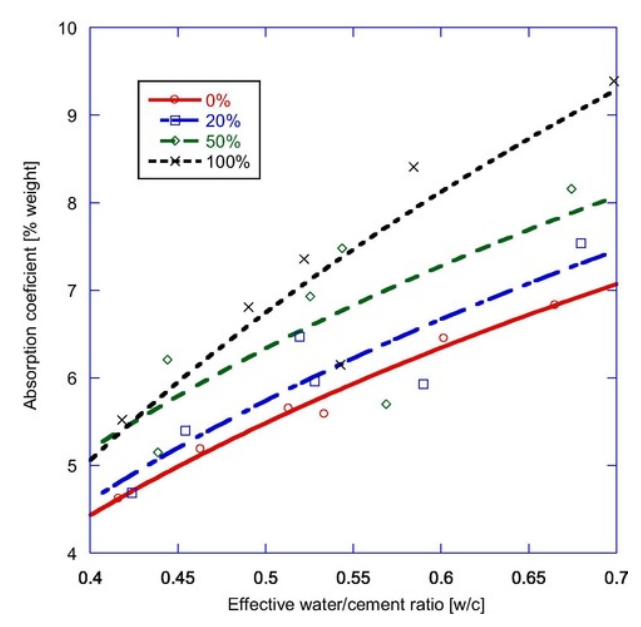

Fig. 5 Absorption coefficient of recycled concretes with 28 days cured into marine environment.

\subsection{Porosity}

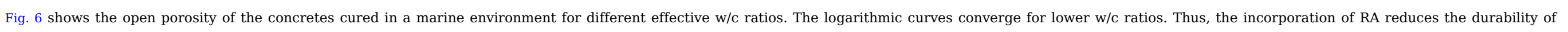




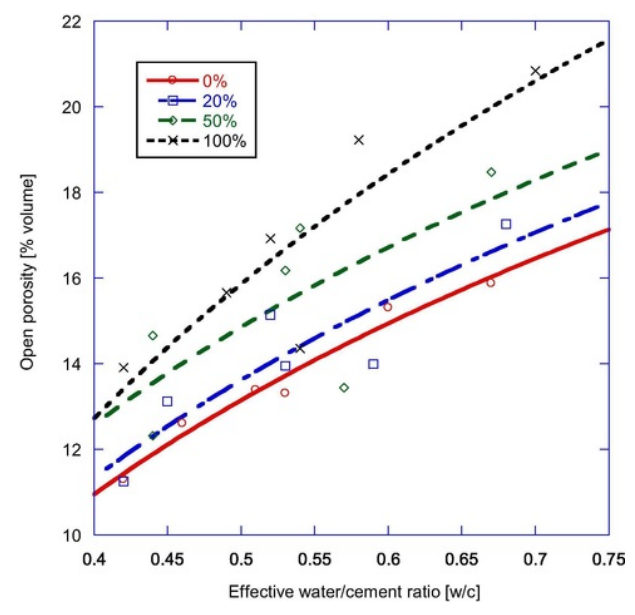

\section{Fig. 6 Open porosity of recycled concretes with 28 days cured into marine environment.}

\subsection{Water penetration}

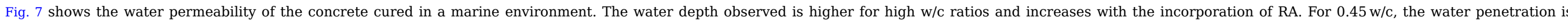

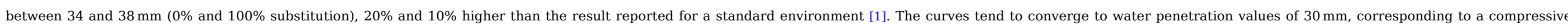

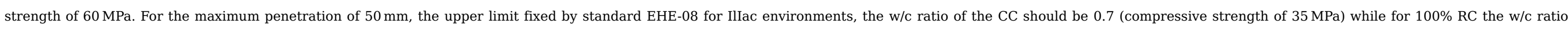
should be 0.55 (compressive strength $40 \mathrm{MPa}$ )

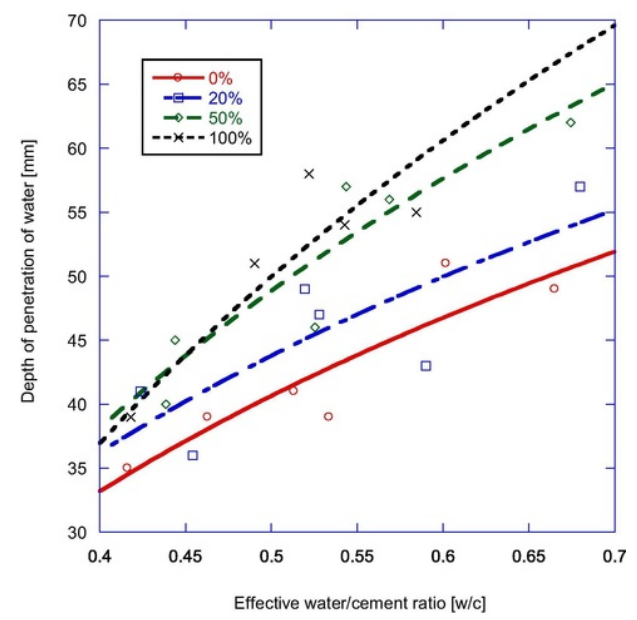

Fig. 7 Water deep penetration of recycled concretes with 28 days cured into marine environment.

\subsection{Oxygen permeability}

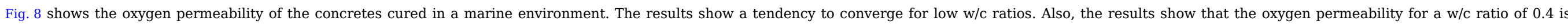




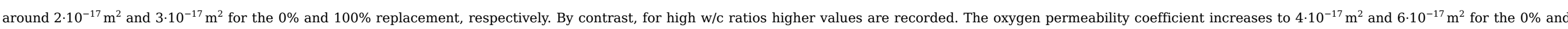

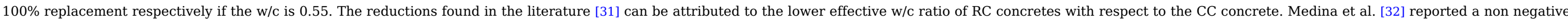

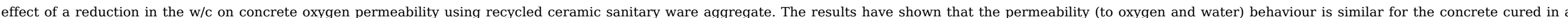
marine environment.

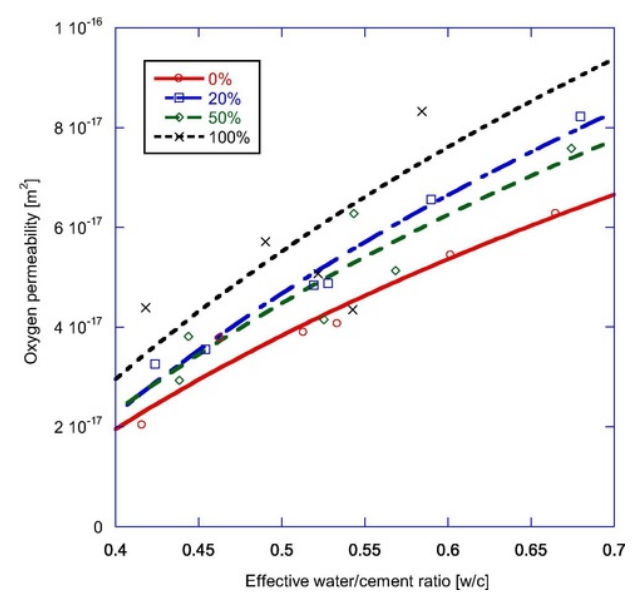

Fig. 8 Oxygen permeability of recycled concretes with 28 days cured into marine environment.

\subsection{Accelerated chloride penetration}

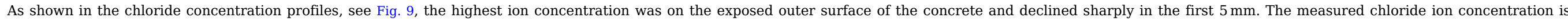

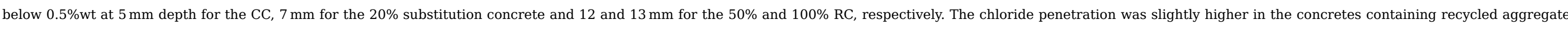
than in the control concretes.

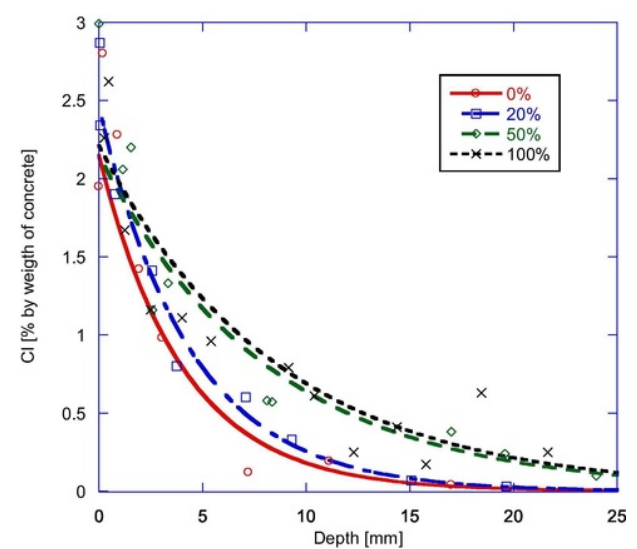

Fig. $9 \mathrm{Cl}$ weight detected in the cement paste vs. the depth from the exposed outermost surface.

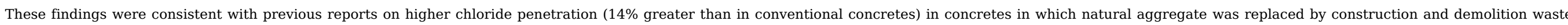

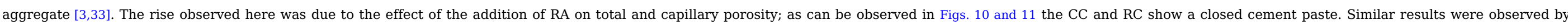
Moon et al. [34] and [3]. 


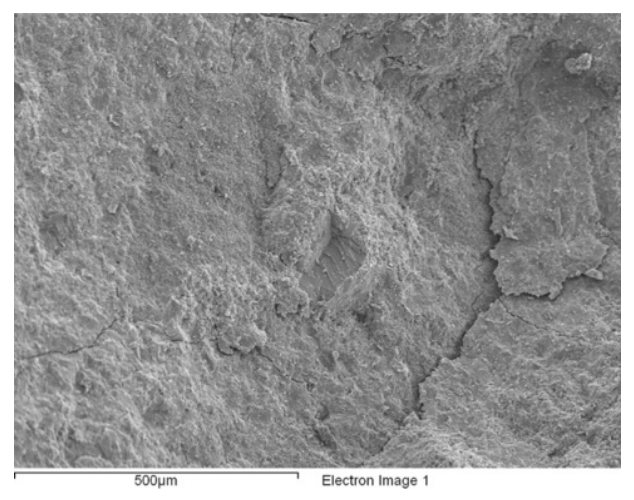

Fig. 10 Micrograph of a RC-DA-0,50-0\% tested sample microstructure.

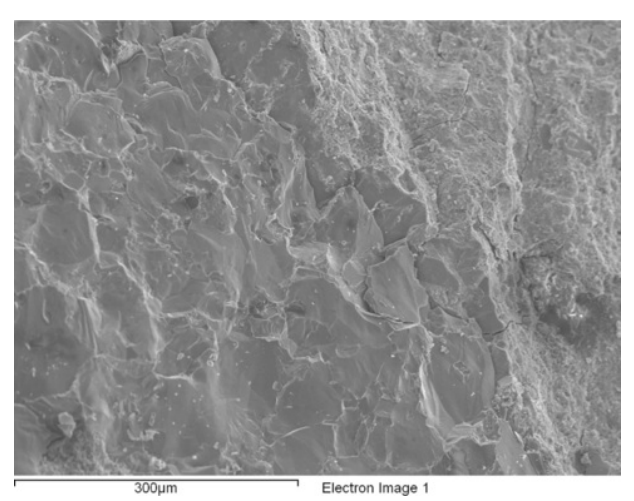

Fig. 11 Micrograph of a RC-DA-0,50-100\% tested sample microstructure.

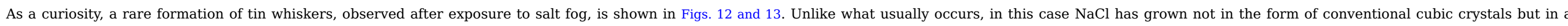

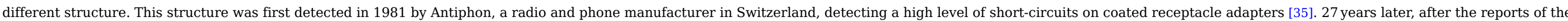
NASA Tin Whisker Homepage (http://nepp.nasa.gov/whisker), P. Fontana and R. Pock used a scanning electron microscope (SEM) to observe the same sample again [36].

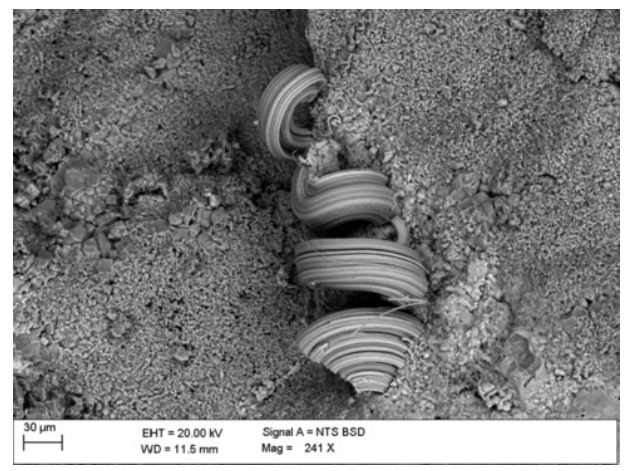

Fig. 12 Micrograph of tin whiskers found into a tested sample after salt fog exposure. 


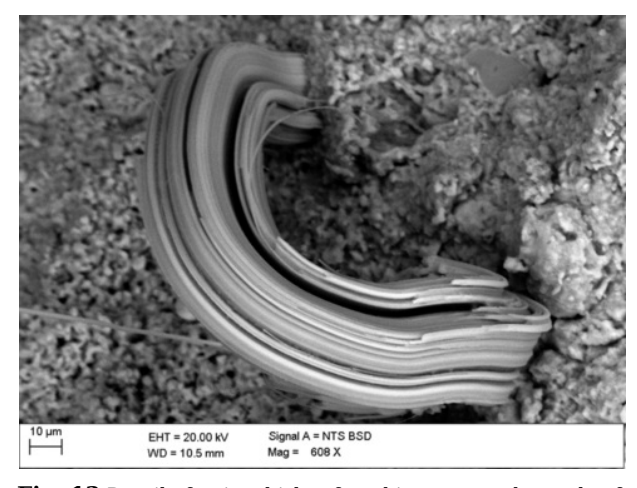

Fig. 13 Detail of a tin whisker found into a tested sample after salt fog exposure.

\section{Conclusions}

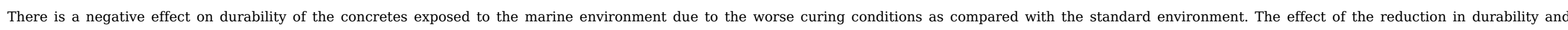
mechanical properties is more significant for the high cement content concretes.

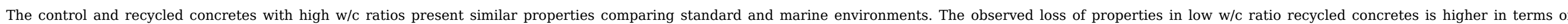
mechanical properties than for the durability properties.

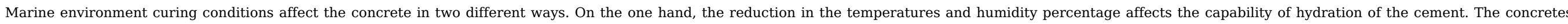

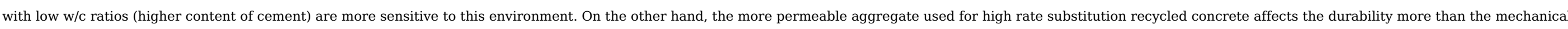
properties. However, substitutions of $20 \%$ in weight of the natural coarse aggregate provide similar values to that of the control concrete

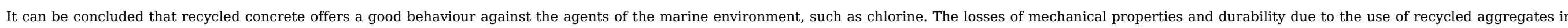

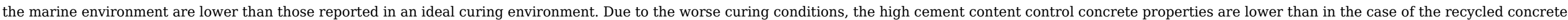

\section{Acknowledgments}

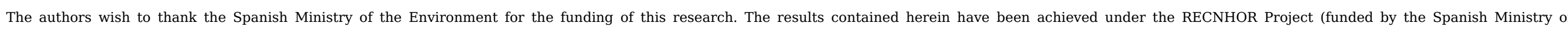

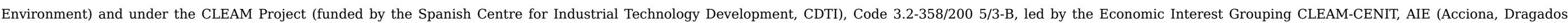
Ferrovial, FCC, Sioux, OHL and Sacyr) and SMEs Informatica 68, Quilosa and Martinez Segovia and associates.

The authors declare that they have no conflict of interest.

\section{References}

[1] C. Thomas, J. Setién, J.A. Polanco, P. Alaejos and M.S. de Juan, Durability of recycled aggregate concrete, Constr. Build. Mater. 40, $2013,1054-1065$.

[2] C. Thomas, J. Setién and J.A. Polanco, Structural recycled aggregate concrete made with precast wastes, Constr. Build. Mater. 114, 2016, 536-546, 7/1.

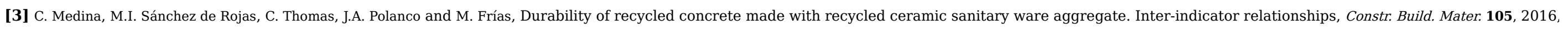
480-486.

[4] S.C. Kou and C.S. Poon, Long-term mechanical and durability properties of recycled aggregate concrete prepared with the incorporation of fly ash, Cem. Concr. Compos. 37, 2013, 12-19, 3.

[5] C. Thomas, I. Sosa, J. Setién, J.A. Polanco and A.I. Cimentada, Evaluation of the fatigue behaviour of recycled aggregate concrete, J. Clean. Prod. 65, 2014 , 397-405. 
[6] C. Thomas, J. Setién, J.A. Polanco, I. Lombillo and A. Cimentada, Fatigue limit of recycled aggregate concrete, Constr. Build. Mater. 52, 2014, 146-154.

[7] K. Onoue, M. Tokitsu, M. Ohtsu and T.A. Bier, Fatigue characteristics of steel-making slag concrete under compression in submerged condition, Constr. Build. Mater. 70, 2014 , 231-242, 11/15.

[8] J. Xiao, H. Li and Z. Yang, Fatigue behavior of recycled aggregate concrete under compression and bending cyclic loadings, Constr. Build. Mater. 38, 2013 , 681-688, 1.

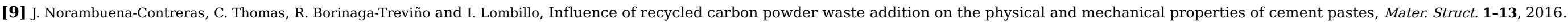

[10] C. Thomas, P.H.R. Borges, T.H. Panzera, A. Cimentada and I. Lombillo, Epoxy composites containing CFRP powder wastes, Compos. Part B Eng. 59, $2014,260-268$.

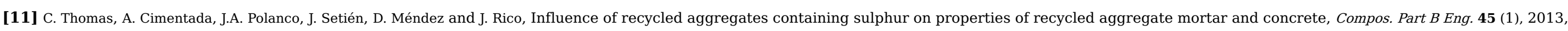
474-485.

[12] UNE-EN 206-1, Hormigón. Parte 1: Especificaciones, prestaciones, producción y conformidad, 2008.

[13] M.S. de Juan and P.A. Gutiérrez, Study on the influence of attached mortar content on the properties of recycled concrete aggregate, Constr. Build. Mater. 23 (2), 2009 , 872-877.

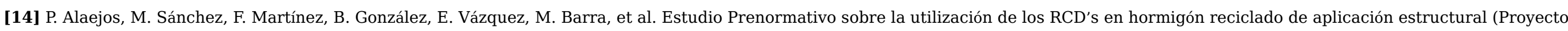
RECNHOR) y Reciclado de los RCD's como áridos de hormigones estructurales (Proyecto CLEAM): IECA - Instituto Español del Cemento y sus Aplicaciones; 2011.

[15] EN 12390-1, Testing hardened concrete. Part 1: Shape, dimensions and other requirements for specimens and moulds, 2001.

[16] EN 12390-2, Testing hardened concrete - Part 2: Making and curing specimens for strength tests, 2009.

[17] EN 12390-3, Testing hardened concrete - Part 3: Compressive strength of test specimens, 2009.

[18] EN 12390-4, Testing hardened concrete - Part 4: Compressive strength - Specification for testing machines, 2001.

[19] EN-12390-6, Testing hardened concrete - Part 6: Tensile splitting strength of test specimens, 2010.

[20] UNE-83316, Concrete tests. Determination of the modulus of elasticity in compression. 1996.

[21] EN-12390-7, Testing hardened concrete - Part 7: Density of hardened concrete. 2009.

[22] EN-12390-8, Testing hardened concrete - Part 8: Depth of penetration of water under pressure, 2009.

[23] UNE 83966, Concrete durability, Test methods. Conditioning of concrete test pieces for the purpose of gas permeability and capilar suction tests, 2008 .

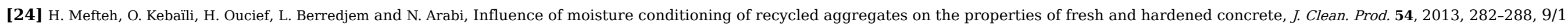

[25] B.L. Damineli, F.M. Kemeid, P.S. Aguiar and V.M. John, Measuring the eco-efficiency of cement use, Cem. Concr. Compos. 32 (8), $2010,555-562,9$.

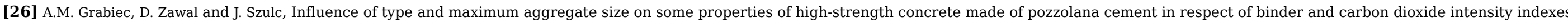
Constr. Build. Mater. 98, 2015, 17-24, 11/15.

[27] A. Barbudo, J. de Brito, L. Evangelista, M. Bravo, F. Agrela. Influence of water-reducing admixtures on the mechanical performance of recycled concrete. J.Clean.Prod. (0).

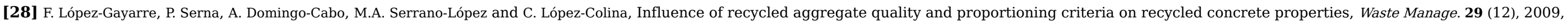
3022-3028, 12.

[29] C.J. Zega and A.A. Di Maio, Use of recycled fine aggregate in concretes with durable requirements, Waste Manage. 31 (11), 2011, 2336-2340, 11.

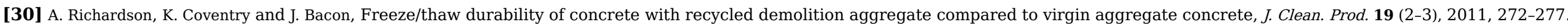

[31] F.T. Olorunsogo and N. Padayachee, Performance of recycled aggregate concrete monitored by durability indexes, Cem. Concr. Res. 32 (2), $2002,179-185,11$. 


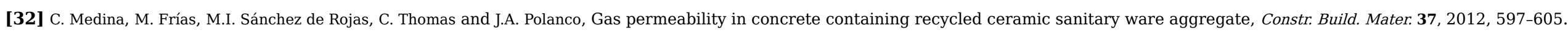

[33] M. Chakradhara Rao, S.K. Bhattacharyya and S.V. Barai, Influence of field recycled coarse aggregate on properties of concrete, Mater. Struct. 44 (1), 2011, 205-220.

[34] H.Y. Moon, H.S. Kim and D.S. Choi, Relationship between average pore diameter and chloride diffusivity in various concretes, Constr. Build. Mater. 20 (9), 2006, 725-732, 11.

[35] George T. Galyon, A History of Tin Whisker Theory: 1946 to 2004. IBM eSG Group http://thor.inemi.org/webdownload/newsroom/Presentations/SMTAI-04_tin_whiskers.pdf.

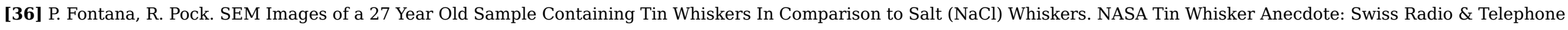
2008;https://nepp.nasa.gov/whisker/anecdote/1981phone/.

\section{Highlights}

- The physical and mechanieal properties of the

- Higher durabilitv reduction for low w/c ratio than for mechanical propierties. There is a nNegative effect on durability due to the expesure to the marine envirenment due to the-worst curing conditions.

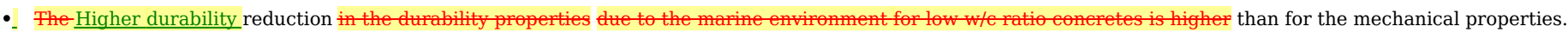

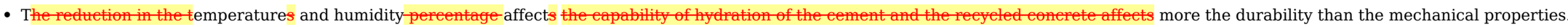

\section{Queries and Answers}

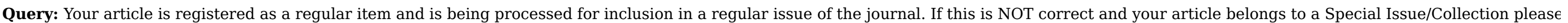
contact t.gunasekaran.1@elsevier.com immediately prior to returning your corrections.

Answer: The article is a regular item

Query: The author names have been tagged as given names and surnames (surnames are highlighted in teal color). Please confirm if they have been identified correctly. Answer: Comfirmed

Query: Highlights should only consist of 85 characters per bullet point, including spaces. The highlights provided are too long; please edit them to meet the requirement.

Answer: New Highlights (attached): - Humidity chamber and marine environment have been analysed.

- Negative effect on durability due to the worst curing conditions.

- Higher durability reduction for low w/c ratio than for the mechanical properties.

- Temperatures and humidity affect more the durability than the mechanical properties.

Attachments: Highlights.docx 